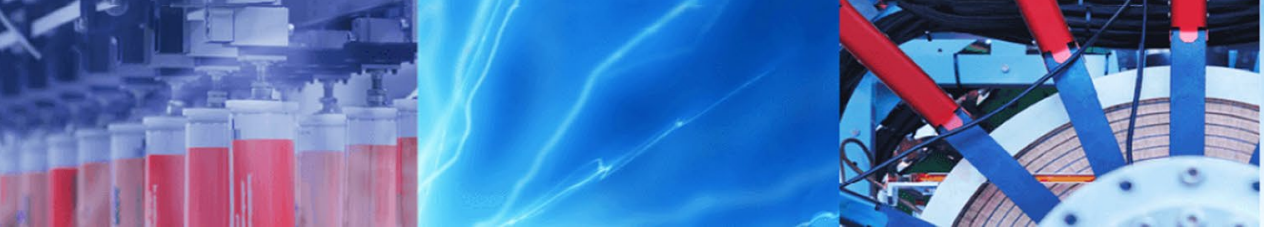

Research Article

\title{
Electrochemical performances of activated carbon prepared using eggshell waste
}

\author{
V. Balasubramanian ${ }^{1} \cdot$ T. Daniel $^{1} \cdot$ J. Henry ${ }^{1} \cdot$ G. Sivakumar ${ }^{2} \cdot$ K. Mohanraj ${ }^{1}$ (I)
}

Received: 9 October 2019 / Accepted: 18 December 2019 / Published online: 21 December 2019

(c) Springer Nature Switzerland AG 2019

\begin{abstract}
This paper describes the preparation of activated carbon (Ac) from broiler hen eggshell (BES) and Country hen eggshell (CES) waste with the assistance of chemical activating agent orthophosphoric acid $\left(\mathrm{H}_{3} \mathrm{PO}_{4}\right)$ and eggshell powder for 4:1 and 4:2 concentrations. XRD analysis affirmed the formation of $\mathrm{Ac}$ and the hexagonal structure of $\mathrm{CaCO}_{3}$ for both $\mathrm{BES}$ and CES samples. The average crystalline size, dislocation density, microstrain, lattice parameter, and cell volume values are found to be higher for CES. The FTIR spectra confirmed the presence of functional groups of BES and CES samples of Ac. UV-DRS spectra exhibited strong absorption in the visible region for BES and the bandgap value is found to be around $1.2 \mathrm{eV}$ for both $\mathrm{BES}$ and CES. The surface morphology reveals the porous nature, irregular shape and uniform size particles of Ac. Cyclic voltammetry and electrochemical impedance spectroscopy measurements were performed to study the energy storage application. Though both BES and CES have showed the capacitive behavior, the sample BES exhibit higher specific capacitance of $155.8 \mathrm{~F} / \mathrm{g}$ is achieved for BES than CES. Similarly, the $R_{s}$ and $R_{c t}$ values are calculated from the impedance measurement and it is found to be lower for BES sample that indicates improved electrical conductivity.
\end{abstract}

Keywords Activated carbon · Eggshell · Ortho-phosphoric acid · Specific capacitance

\section{Introduction}

Activated carbon (Ac) being a carbonaceous material, predominantly amorphous in nature and has high porosity due to the production and treatment. In the recent years, the use of agricultural waste biomass such as waste coffee beans [1], cassava peel waste [2], bamboo waste [3], sugarcane bagasse [4, 5], rice husk [6], peanut shell [7], rubberwood, saw dust [8] act as a precursor material to prepare porous carbon for electric double layer capacitors (EDLC) due to their abundant availability and low cost. The large amount of egg waste creates an environmentally and economically challenging problem if it is not managed suitably [11]. Moreover, activated carbon has special features like absorption of heavy metal ion and organic pollutants which results in increased antibacterial effect.
The eggshell's composition consists of calcium carbonate (94\%), calcium phosphate (1\%), magnesium carbonate (1\%), organic substances (4\%) [12]. Bio derived activated carbon-based materials have been employed as a high performance supercapacitor applications due to their intrinsic and extrinsic characteristics such as high electronic conductivity, high surface area, low cost, affordability to large scale applications. Zhang et al. [9] achieved a high energy density supercapacitor of 17.2 and $87.8 \mathrm{Wh} /$ $\mathrm{kg}$ in both acidic and organic electrolytes for nitrogen doped commercial activated carbon. Bhomick et al. [10] reported both experimental and theoretical investigation of $\mathrm{KOH}$ synthesized activated carbon using Schima wallichii biomass by varying the carbonization temperature. Sivachidambaram et al. [11] prepared activated carbonbased electrode material from the Borassus flabellifer

K. Mohanraj, kmohanraj.msu@gmail.com; mohanraj@msuniv.ac.in | ${ }^{1}$ Department of Physics, Manonmaniam Sundaranar University, Tirunelveli, Tamil Nadu 627 012, India. ${ }^{2} \mathrm{CISL}$, Department of Physics, Annamalai University, Annamalai Nagar, Tamil Nadu 608002, India. 
flower for analyzing supercapacitor behavior. Li et al. [12] prepared carbonized chicken eggshell membrane with 3D architecture as high performance electrode materials for supercapacitors. Meng et al. [13] has investigated supercapacitor behavior of waste eggshell used as reactor and template for synthesis of $\mathrm{Co}_{9} \mathrm{~S}_{8}$ nanorod arrays on carbon fibers for energy storage. Jose et al. [14] fabricated highly flexible hierarchical polypyrrole/carbon nanotube on eggshell membranes for supercapacitors and calculated that the areal capacitance of $564.5 \mathrm{mF} / \mathrm{cm}^{2}$ and volumetric capacitance of $24.8 \mathrm{~F} / \mathrm{cm}^{3}$ respectively. Pingping et al. [15] prepared biowaste-derived three-dimensional porous network carbon and bio separator and achieved highperformance asymmetric supercapacitive performance $(478.5 \mathrm{~F} / \mathrm{g})$ at a current density of $500 \mathrm{~mA} / \mathrm{g}$. Therefore, it is observed from the literature that the utilization of eggshell waste for generating activated carbon is not explored well and there is a paucity of reports on this material. Hence, it is motivated to synthesis activated carbon from eggshell waste as a precursor material for energy storage application.

\section{Experimental methods}

\subsection{Preparation of activated carbon}

Generally, eggshell is varied depends on the type of hen. Here we have taken two different kinds of eggshell; broiler hen and Country hen eggshell named as BES and CES were collected separately from the residential wastes. First, the shells were washed with distilled water several times to remove the impurities. Then they were air dried and ground using a mortar to get the finely powdered sample. The powder sample was taken in the crucible and placed in an oven for $6 \mathrm{~h}$ at $110^{\circ} \mathrm{C}$. The obtained product was chemically activated using $\mathrm{H}_{3} \mathrm{PO}_{4}$ (orthophosphoric acid), in which the sample was soaked for $24 \mathrm{~h}$. The sample BES and CES were prepared by mixing $4 \%$ of $\mathrm{H}_{3} \mathrm{PO}_{4}$ with $1 \%$ of activated carbon for $4: 1$ and $4 \%$ of $\mathrm{H}_{3} \mathrm{PO}_{4}$ with $2 \%$ of activated carbon for $4: 2$ respectively. The precursor solution was stirred well for $2 \mathrm{~h}$. Then pour it for filtration and the collected samples were again dried at $110^{\circ} \mathrm{C}$ for $24 \mathrm{~h}$ in oven followed by heating at $550^{\circ} \mathrm{C}$ for $2 \mathrm{~h}$. The powder was rinsed using $1 \mathrm{M}$ of conc. $\mathrm{HCl}$ and distilled water to remove residual inorganic matter. Finally, the activated carbon is obtained and stored for further investigations.

\subsection{Characterization technique}

The structural property of the activated carbon was characterized using XPERT-PRO diffractometer system with a characteristic wavelength of $1.5406 \AA$ for the Ka radiation. XRD was recorded using PANalytical X'Pert Pro diffractometer with tube voltage of $30 \mathrm{kV}$ and the current $40 \mathrm{~A}$. The presence of various functional groups was identified from the Perkin Elmer-spectrum two Fourier transform infra-red (FTIR) spectrometer in the range $4000-400 \mathrm{~cm}^{-1}$. The surface morphology study was carried out using EVO18 (CARL ZEISS) scanning electron microscope. The optical bandgap of the samples was calculated from the reflectance spectra (DRS) recorded using UV-visible spectrophotometer (Shimadzu UV 2600) in the wavelength region $220-850 \mathrm{~nm}$ and $\mathrm{BaSO}_{4}$ were used as reference. The electrochemical measurements were performed in the conventional three-electrode system using $\mathrm{CH} 1604 \mathrm{E}$ electrochemical workstation. Here, $0.5 \mathrm{M} \mathrm{H}_{2} \mathrm{SO}_{4}$ was used as the electrolyte, while the working electrodes were prepared by mixing the electroactive material with polyvinyl alcohol and coated in a stainless steel substrate with an exactly $1 \mathrm{~cm}^{2}$ active area. A large surface area platinum mesh and $\mathrm{Ag} / \mathrm{AgCl}$ electrode were used as counter and reference electrode respectively. The electrochemical performances of the fabricated electrode were characterized by cyclic voltammetry (CV) and electrochemical impedance spectroscopy (EIS) measurements. The CV curves were recorded at various scan rates $(10,50,100$ and 200 $\mathrm{mV} / \mathrm{s}$ ) in a potential window of -1.5 to $+1.5 \mathrm{~V}$. The EIS measurements were carried out in the frequency range of $0.1 \mathrm{~Hz}$ to $100 \mathrm{kHz}$ with an AC amplitude of $5 \mathrm{mV}$.

Proximate analysis of activated carbon was determined according to Ekpete et al. [16].

\section{(i) Ash content}

Ash content is the measure of the mineral oxide content of activated carbon on a weight basis. It is measured by converting the mineral oxides to the respective oxides at $800^{\circ} \mathrm{C}$.

$\left\{\left(M_{c}+M_{a}\right)-M_{c} /\left(M_{c}+M_{s}\right)-M_{c}\right\} \times 100$

where $M_{c}$ is the mass of the crucible, $M_{a}$ is the mass of the ash, $M_{s}$ is the mass of the sample.

\section{(ii) Moisture content}

The moisture content of activated carbon is measured as weight loss after heating at $150^{\circ} \mathrm{C}$ and allowed to dry to a constant weight.

$\left(w_{w}-W_{d} / W_{w}\right) \times 100$

where $W_{w}$ is the amount of sample before drying, $W_{d}$ is the amount of sample after drying.

(iii) Specific gravity 
The relative density bottles were cleaned, dried and weighed empty. One-third of the activated carbons were put into it and weighed again. The relative density bottles were filled with water and reweighed. Finally, the bottles were emptied, cleaned of the activated carbon particles filled with water alone and weighed.

\section{(iv) Bulk density}

A cylinder and an aluminium plate were each weighed. A sample of activated carbon was put into the cylinder and reweighed. The samples were transferred into the aluminium plate and put into an oven so as to dry it to constant weight at a temperature of $105^{\circ} \mathrm{C}$ for $1 \mathrm{~h}$. The weight of the dried samples was taken again after drying. A clean dry well-corked density bottle was weighed.

Bulk density $=$ Mass of wet sample/mass of volume

\section{Result and discussion}

From the proximate analysis, the total ash content, moisture content, specific gravity and bulk density for BES and CES in given in Table 1 for comparison.

From the table, it is observed that all the physical parameters were matched with the commercial activated carbon [16]. Hence, it is affirmed the presence of activated carbon along with $\mathrm{CaCO}_{3}$.

The X-ray diffraction pattern of grounded cum heated hen eggshell (BES) at $110^{\circ} \mathrm{C}$ is shown in Fig. 1. The reaction mechanism can be understood by the following equations:

$\mathrm{CaCO}_{3}$ + heat $\rightarrow \mathrm{CaO}+\mathrm{CO}_{2}$

$\mathrm{CaO}+\mathrm{H}_{3} \mathrm{PO}_{4} \rightarrow \mathrm{CaHPO}_{4}+\mathrm{H}_{2} \mathrm{O}$

In the diffraction pattern, a prominent and high intense crystalline peak appears at $2 \theta=29.66^{\circ}$ belongs to 110 plane of hexagonal structure of carbon (JCPDS: 460943 ) and the remaining crystalline peaks at $2 \theta=23.66^{\circ}$, $2 \theta=29.54^{\circ}$, and $2 \theta=36.28^{\circ}$ belongs to the rhombohedral structure of $\mathrm{CaCO}_{3}$ (JCPDS: 050586). In the case of $\mathrm{H}_{3} \mathrm{PO}_{4}$ activated samples (4:1), the major crystalline peaks appears at $2 \theta=29.25^{\circ}$ and $2 \theta=31.04^{\circ}$ belongs to the hexagonal structure of carbon and these peaks are

Table 1 Proximate analysis of BES, CES and activated carbon

\begin{tabular}{lllll}
\hline S. no. & Parameter & BES & CES & Activated carbon \\
\hline 1. & Total ash content & $2.3 \%$ & $1.8 \%$ & $17.1 \%$ \\
2. & Moisture content & $10 \%$ & $8.3 \%$ & $16.67 \%$ \\
3. & Specific gravity & 0.54 & 0.63 & 1.8 \\
4. & Bulk density $\left(\mathrm{g} / \mathrm{cm}^{3}\right)$ & 0.57 & 0.64 & 0.66 \\
\hline
\end{tabular}

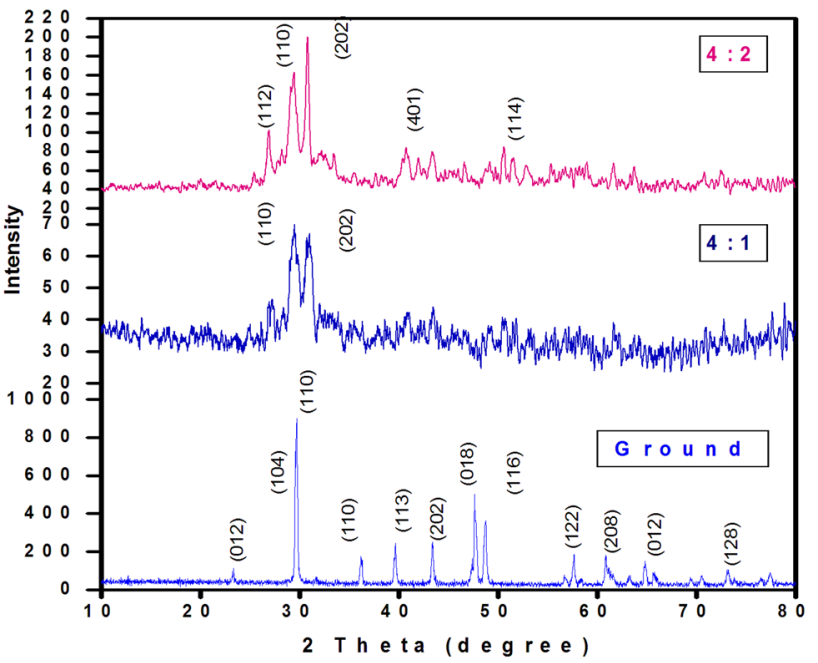

Fig. 1 XRD pattern of Ac received from grounded, 4:1 and 4:2 concentration of BES

slightly shifted in $4: 2$ concentration from $2 \theta=29.25^{\circ}$ and $2 \theta=31.04^{\circ}$ to $2 \theta=29.30^{\circ}$ and $2 \theta=30.77^{\circ}$. This may be attributed to the increase the $\mathrm{H}_{3} \mathrm{PO}_{4}$ content associated with the biochemical content variation in the eggshell waste [17]. The non-existence of majority of the activated carbon peaks related to $\mathrm{CaCO}_{3}$ in the patterns suggests that carbon fibers exhibit less activation in 4:1 and 4:2 concentration, which could be attributed to the relatively low carbonization temperature of $550^{\circ} \mathrm{C}$.

In the case of CES (Fig. 2), the XRD pattern of the grounded CES sample seems to be similar to that of $\mathrm{BES}$ with a slight variation in the intensity. $\mathrm{On}_{3} \mathrm{PO}_{4}$ activation, the crystalline peaks of CES (4:1 concentration) are

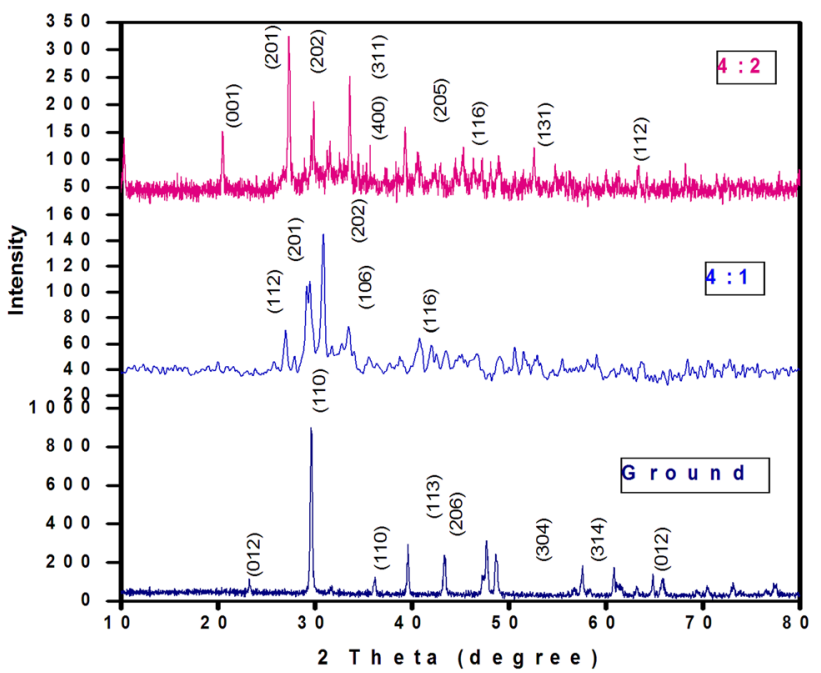

Fig. 2 XRD pattern of Ac received from grounded, 4:1 and 4:2 concentration of CES 
well-matched with Carbon (JCPDS: 460943) and the major crystalline peak appears at $2 \theta=29.85^{\circ}$ belongs to 110 plane. Similarly, carbon peaks are observed at $2 \theta=33.59^{\circ}$, $2 \theta=34.49^{\circ}$, and $2 \theta=39.37^{\circ}$ for $4: 2$ concentration and remaining peaks belongs to $\mathrm{CaCO}_{3}$. By comparing the both BES and CES, the samples prepared using 4:1 concentration is well agreed with carbon and further increase the concentration (4:2), leads to the formation of $\mathrm{CaCO}_{3}$ for both BES and CES as may be attributed to type of eggshell and thermal energy produced strain in the sample. The intensity and broadening of the peaks are almost identical in BES and CES samples. The result agrees well with the earlier report on activated carbon from eggshell membranes prepared using sodium acetate and zinc metal activation [18].

The average crystallite size of both ground cum heated samples and activated samples were calculated using Scherrer formula [19] given by

$\mathrm{D}=0.9 \lambda / \beta \operatorname{Cos} \theta$

The strain $(\varepsilon)$ and dislocation density $(\delta)$ of the Eggshell samples were calculated using the formula given by

$\varepsilon=\beta / \tan \theta$

$\delta=1 / d^{2}$

The lattice parameter and cell volume value were calculated using unit cell software and their results are tabulated in Table 2. It is noticed that the crystalline size, dislocation density, microstrain, lattice parameter, and cell volume values are higher for CES which may be attributed to the type of the samples.

The FTIR spectra of raw-cum heated samples are shown in Fig. 3. By comparing the vibrational spectra, the position of the bands/peaks are identical to each other, however, its variation in intensity is observed and are summarized in Table 3. In both BES and CES, a broad and strong peak is observed at $1420 \mathrm{~cm}^{-1}$ and a sharp peak appears at $870 \mathrm{~cm}^{-1}$ due to stretching and bending vibration of

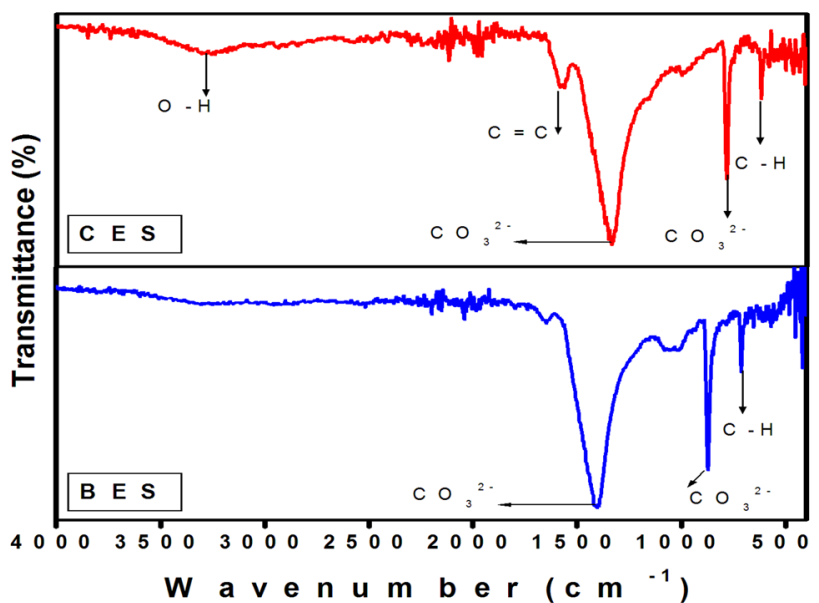

Fig. 3 FTIR spectra of grounded BES and CES samples

carbonate group present in the sample [20,21]. In addition, the characteristic peak of carbon is found around $1630 \mathrm{~cm}^{-1}$ belongs to $C=C$ vibration.

Figure $4 a$, $b$ shows the FTIR spectra of Ac BES and CES for $4: 1$ and $4: 2$ concentration respectively. It is important to notice that the sharp peaks that appeared at $870 \mathrm{~cm}^{-1}$ in the ground cum heated samples is disappeared in the activated samples. While a band appears around $930 \mathrm{~cm}^{-1}$ with weak intense band at $712 \mathrm{~cm}^{-1}$ which is due to the bending vibration of $\mathrm{CaCO}_{3}$. In addition, the characteristic peak of carbon $(C=C)$ vibration is observed around $1631 \mathrm{~cm}^{-1}$ for both BES and CES samples. In the FTIR spectra of both BES and CES, a weak peak is observed around $1128 \mathrm{~cm}^{-1}$ and $1070 \mathrm{~cm}^{-1}$ is due to symmetric $\mathrm{P}-\mathrm{O}$ stretching vibration of $\mathrm{PO}_{3}{ }^{2-}$ group which is due to the activating agent used in the materials [22]. A small hump and a weak peak are observed at $556 \mathrm{~cm}^{-1}$ and $448 \mathrm{~cm}^{-1}$ due to the bending vibration of $\mathrm{PO}_{4}{ }^{3-}$ respectively [23]. By comparing the spectra, the vibrational spectra of CES are changed in terms of variation in intensity of the bands that may be due to the presence of protoporphyrin IX pigment present in CES. It is clearly revealed from the FTIR analysis that

Table 2 Crystalline size, dislocation density, micro strain, lattice parameter, cell volume

\begin{tabular}{|c|c|c|c|c|c|c|c|c|}
\hline \multirow[t]{2}{*}{ S. no. } & \multirow[t]{2}{*}{ Concentration } & \multirow[t]{2}{*}{$\begin{array}{l}\text { Resource } \\
\text { material }\end{array}$} & \multirow[t]{2}{*}{$\begin{array}{l}\text { Crystalline size } \\
\left(\times 10^{-9} \mathrm{~m}\right)\end{array}$} & \multirow[t]{2}{*}{$\begin{array}{l}\text { Dislocation density } \\
\left(\times 10^{14} \text { lines } \mathrm{m}^{-2}\right)\end{array}$} & \multirow[t]{2}{*}{$\begin{array}{l}\text { Micro strain } \\
\left(\times 10^{-4}\right)\end{array}$} & \multicolumn{2}{|c|}{$\begin{array}{l}\text { Lattice param- } \\
\text { eter }\end{array}$} & \multirow[t]{2}{*}{ Cell volume, $\mathrm{V}\left(\AA \AA^{3}\right)^{3}$} \\
\hline & & & & & & $\overline{a(\AA)}$ & $c(\AA)$ & \\
\hline \multirow[t]{2}{*}{1.} & \multirow[t]{2}{*}{ Grounded Sample } & BES & 58 & 5 & 2.85 & 4.89 & 17.74 & 368.02 \\
\hline & & CES & 48 & 6 & 6.33 & 7.19 & 17.00 & 759.40 \\
\hline \multirow[t]{2}{*}{2} & \multirow[t]{2}{*}{$4: 1$} & BES & 6 & 1 & 3.48 & 7.08 & 17.09 & 742.88 \\
\hline & & CES & 23 & 75 & 25.95 & 7.10 & 17.05 & 760.49 \\
\hline \multirow[t]{2}{*}{3.} & \multirow[t]{2}{*}{$4: 2$} & BES & 20 & 9 & 6.58 & 7.15 & 17.0 & 754.77 \\
\hline & & CES & 50 & 4 & 7.35 & 7.16 & 17.31 & 770.47 \\
\hline
\end{tabular}


Table 3 FTIR vibrational frequency assignment of BES and CES

\begin{tabular}{|c|c|c|c|c|c|c|c|c|}
\hline \multirow[t]{3}{*}{ S. no. } & \multirow[t]{3}{*}{ Band assignment } & \multicolumn{6}{|c|}{ Observed frequency $\left(\mathrm{cm}^{-1}\right)$} & \multirow[t]{3}{*}{ Frequency } \\
\hline & & \multicolumn{2}{|c|}{$\begin{array}{l}\text { Raw heated } \\
\text { sample }\end{array}$} & \multicolumn{2}{|l|}{$4: 1$} & \multicolumn{2}{|l|}{$4: 2$} & \\
\hline & & BES & CES & BES & CES & BES & CES & \\
\hline 1 & $\mathrm{OH}$ vibration & $3366_{w}$ & $3365_{w}$ & $3366_{b h}$ & $3366_{b}$ & $3366_{w}$ & $3367_{b}$ & $3300-3500$ \\
\hline 2 & $\mathrm{C}=\mathrm{C}$ vibration & $1656_{w}$ & $1627_{w}$ & $1631_{\mathrm{w}}$ & $1627_{w}$ & $1619_{w}$ & $1630_{\mathrm{sp}}$ & 1630 \\
\hline 3 & Vibration of carbonate & $1420_{\text {sp }}$ & $1420_{\text {sp }}$ & - & - & - & - & 1417 \\
\hline 4 & Vibration of $\mathrm{PO}_{3}{ }^{2-}$ & - & - & $1071_{\mathrm{w}^{\prime}} 1128_{\mathrm{w}}$ & $1074_{w}, 1140_{w}$ & $1071_{\mathrm{w}}$ & $1062_{w}$ & 1120,1042 and 1090 \\
\hline 5 & $\begin{array}{l}\text { Vibration of } \mathrm{CaCO}_{3} \\
\text { Vibration of } \mathrm{P}-\mathrm{O}-\mathrm{P} \text { bending }\end{array}$ & - & - & $934_{w}$ & $916_{w}$ & $928_{w}$ & $\begin{array}{l}- \\
946_{w}\end{array}$ & $\begin{array}{l}924 \\
943-980\end{array}$ \\
\hline 6 & Vibration of Carbonate & $870_{\mathrm{sp}}$ & $870_{\mathrm{sp}}$ & - & - & - & - & 875 \\
\hline 7 & $\mathrm{C}-\mathrm{O}$ stretching vibration of $\mathrm{CO}_{3}{ }^{2-}$ group & $712_{w}$ & $712_{w}$ & $712_{w}$ & $712_{w}$ & $712_{w}$ & $712_{w}$ & 715 \\
\hline 8 & Vibration of $\mathrm{PO}_{4}^{3-}$ & - & - & $556_{w h}$ & $550_{h}$ & $563_{w h}$ & $550_{h}$ & $550-600$ \\
\hline 9 & Vibration of $\mathrm{O}-\mathrm{P}-\mathrm{O}$ stretching $\mathrm{Po}_{4}^{2-}$ group & - & - & $488_{w}$ & $491_{w}$ & $488_{w}$ & $491_{w}$ & 484 \\
\hline
\end{tabular}

$w$ weak, $s$ strong, $h$ hump, bh broad hump, wh weak hump, sp sharp peak

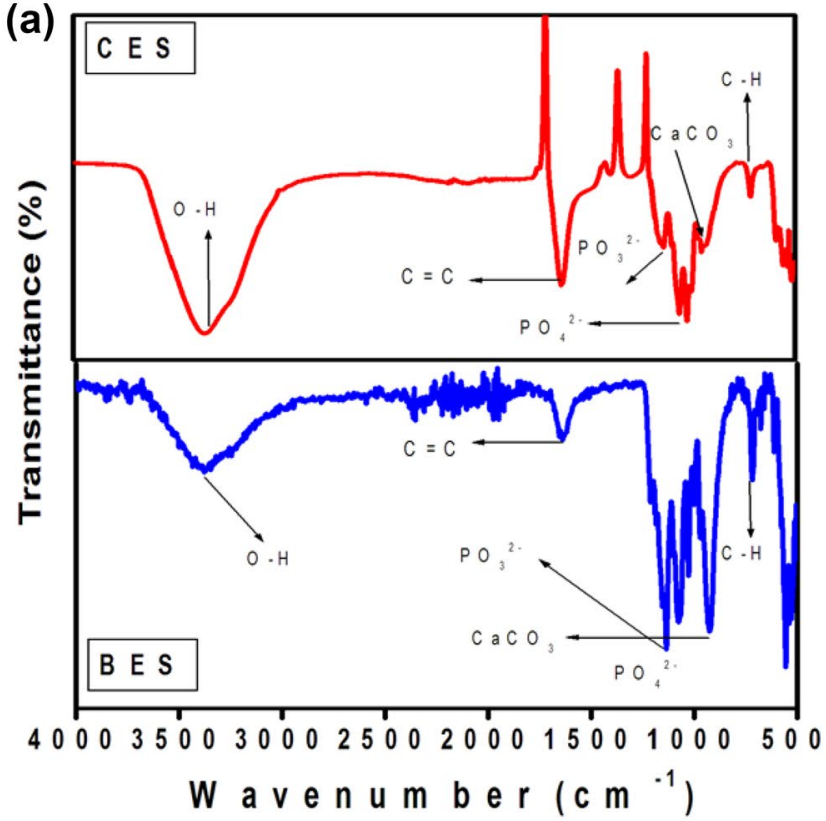

Fig. 4 FTIR spectra of Ac from BES and CES for $\mathbf{a}$ 4:1 and b 4:2

the activation agent influenced the intensity of carbonyl bands in both eggshell samples.

\subsection{SEM analysis}

Figures 5 and 6 displays the scanning electron microscope (SEM) images of chemically activated BES and CES samples of activated carbon with different magnifications ( $5 \mathrm{kx}, 10 \mathrm{kx}, 20 \mathrm{kx}$ and $50 \mathrm{kx}$ ). It can be seen from the images (BES) that the synthesized particles are highly agglomerated with porous nature which is irregularly distributed

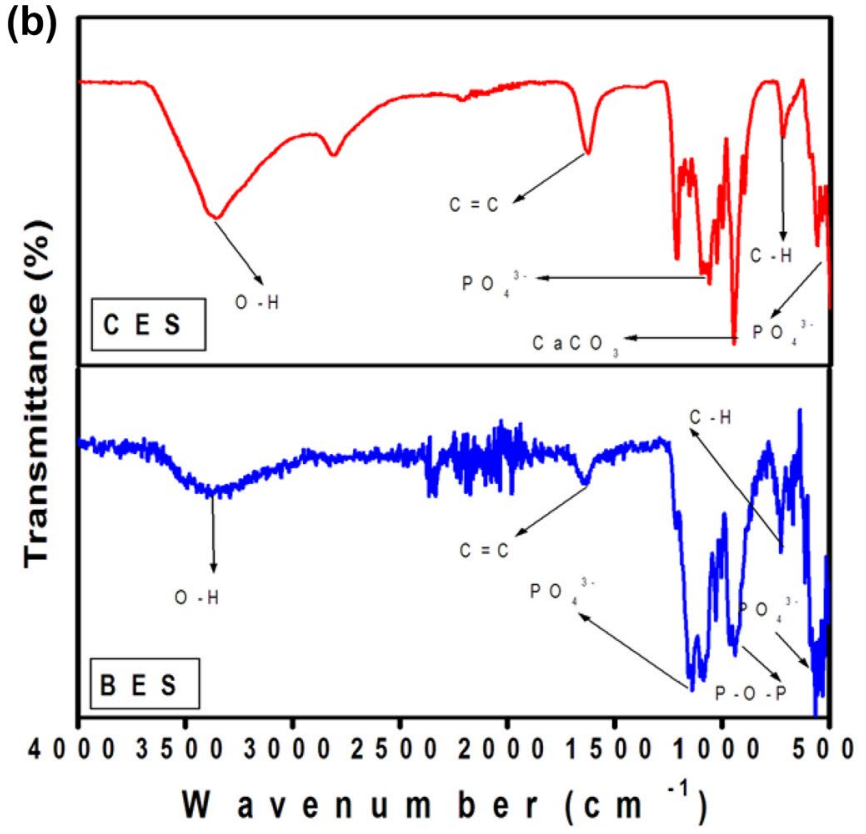

over the surface as clearly shown in the higher magnification images $(50 \mathrm{kx})$. The porous nature may be attributed to the influence of activating agent $\mathrm{H}_{3} \mathrm{PO}_{4}$ on eggshell. The advantage of the porous structure was that it will allow electrolyte penetration which is favorable for ion diffusion, charge transfer and capacitance increases $[24,25]$. In the case of CES, the synthesized particles are flake-like structures and exhibit partial geometrical shape. But, the surface morphology is not dense compared to BES. It could be attributed to the type of eggs shells. This observation is in agreement with XRD and FTIR analysis. Generally 


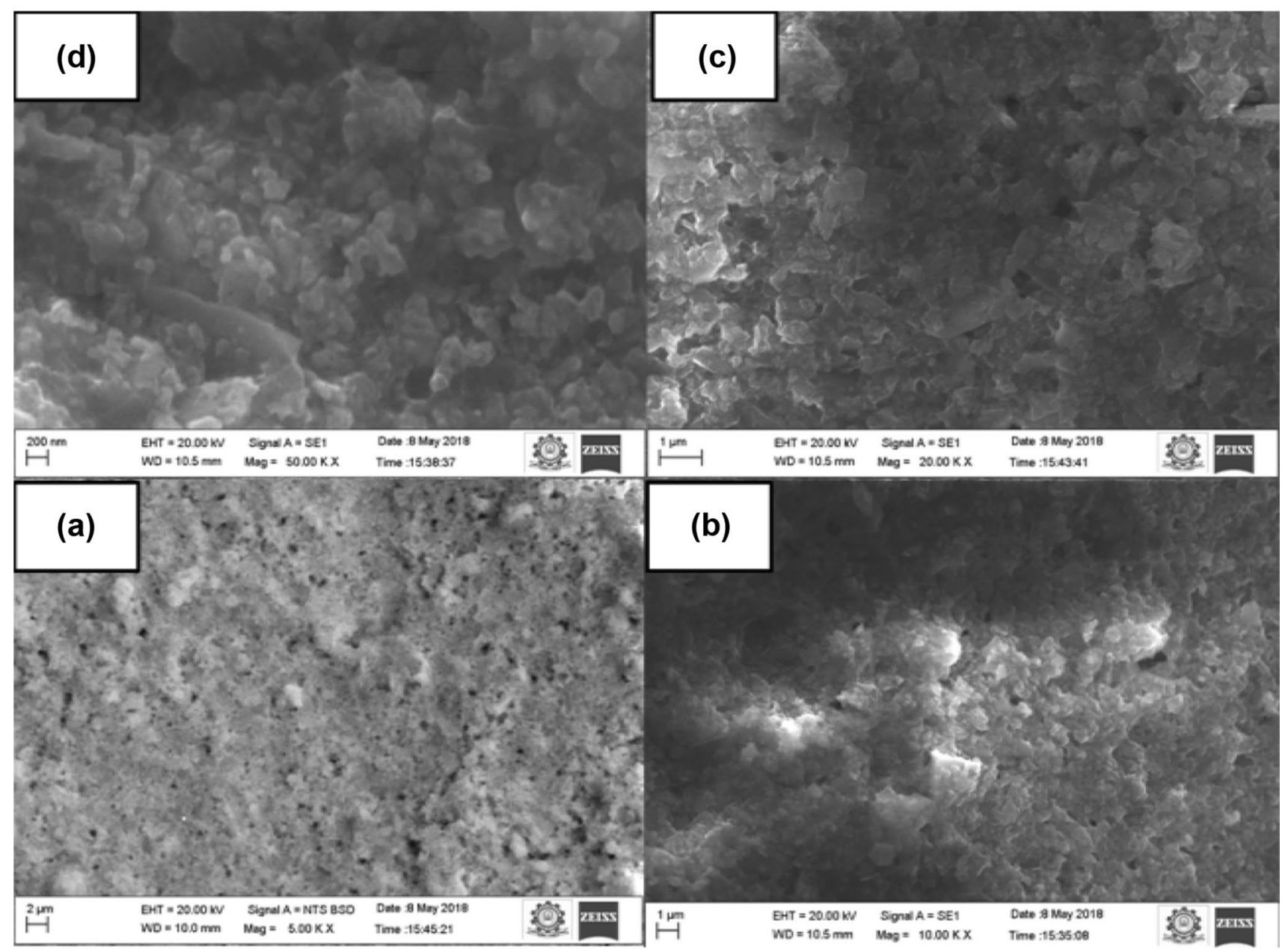

Fig. 5 SEM images of Ac from BES for 4:1 concentration

activated carbon synthesized using various biomaterials always show porous structure. In our study, we also received the porous structure of activated carbon for the BES sample. The high porosity results in increased charge storage characteristics which are in agreement with cyclic voltammetry study [26].

\subsection{DRS analysis}

Figure 7 shows the DRS spectra of activated carbon for 4:1 concentration (carbon: $\mathrm{H}_{3} \mathrm{PO}_{4}$ ). It can be seen from the Fig. 7a that BES exhibited strong absorption in the visible region in comparison to CES. It could be attributed to the increase in the crystalline size of the BES particle $(23 \mathrm{~nm})[27,28]$. Usually bigger size crystallite has fewer grain boundaries, leading to less radioactive combination centers in the material. The reason for decrease the optical absorption in CES may be due to the increase in grain boundaries and defects which increases the maximum scattering of light. Figure $7 b$ shows Ac prepared for $4: 2$ concentration. By comparing the results, the DRS spectra of $4: 2$ are almost identical to the concentration of $4: 1$ and difficult to distinguish the performance of optical absorption as reflected in the band gap value. The bandgap was determined from the DRS using the Kubelka-Munk relation which is given by

$\mathbf{F}\left(\mathbf{R}_{\infty}\right)=\frac{\left[1-\boldsymbol{R}_{\infty}\right]^{2}}{2 \boldsymbol{R}_{\infty}}$

where $F\left(R_{\infty}\right)$ is the absorbance of the sample.

$\left(\mathbf{R}_{\infty}\right)=\frac{\text { Rsample }}{\text { Rstandard }}$

The bandgap (Fig. 8) is found to be around $1.2 \mathrm{eV}$ for both BES and CES samples. Almost the closer value of bandgap of the egg samples are attributed to the increasing amount of chemical activator has finely altered the crystalline structure and morphology of 


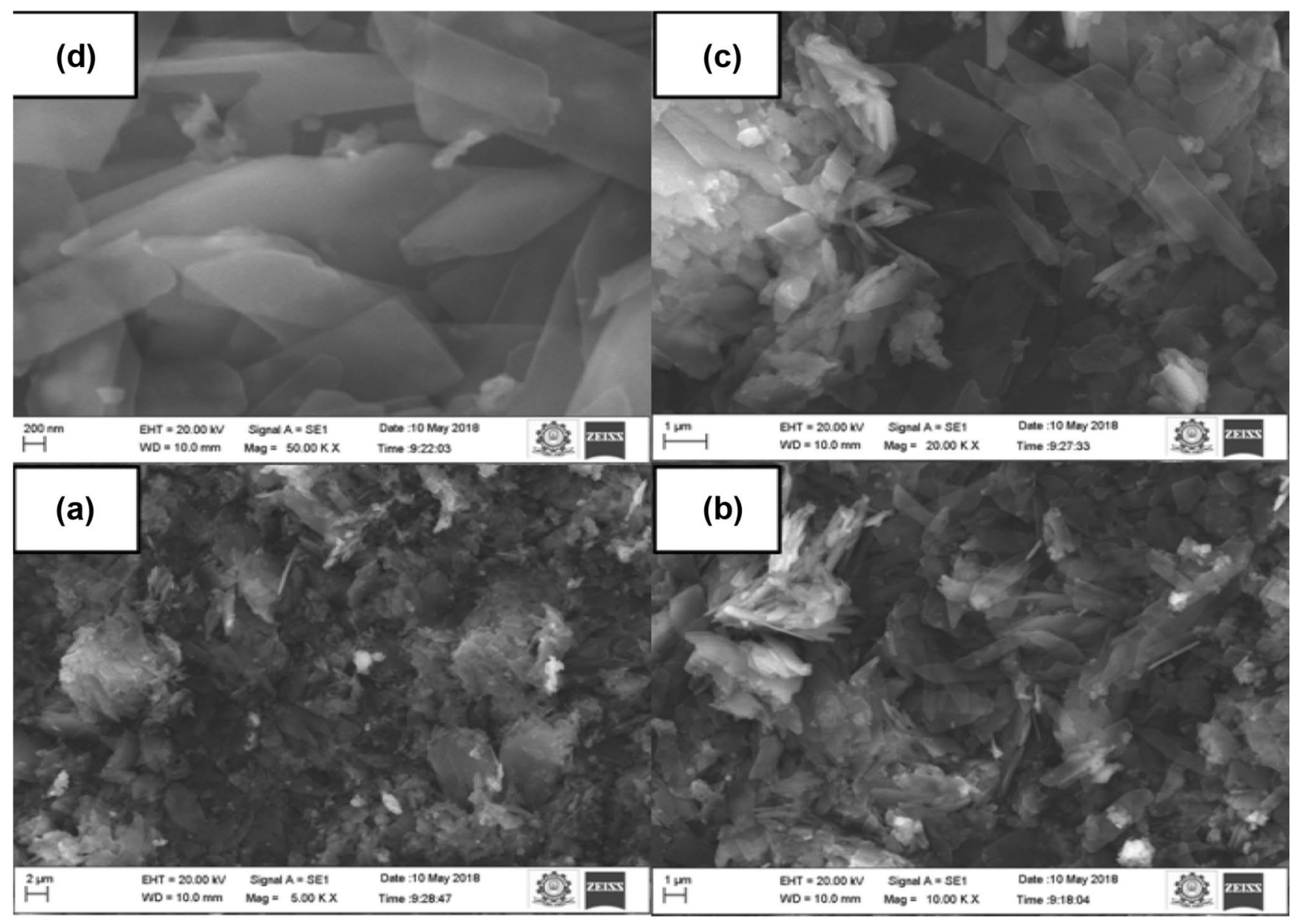

Fig. 6 SEM images of Ac from CES for 4:1 concentration
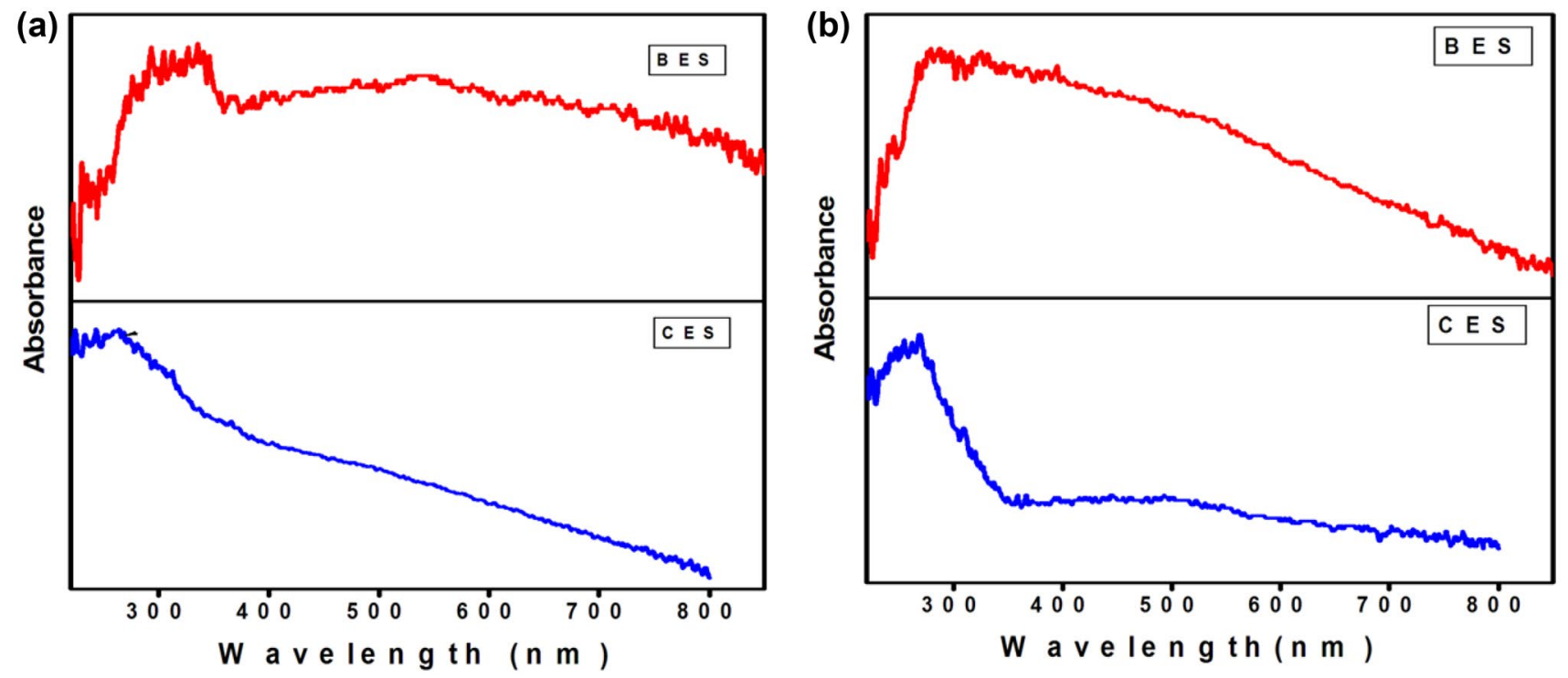

Fig. 7 UV-DRS spectra of Ac from $\mathbf{a} B E S$ and $\mathbf{b}$ CES for 4:1 and 4:2 ratio 

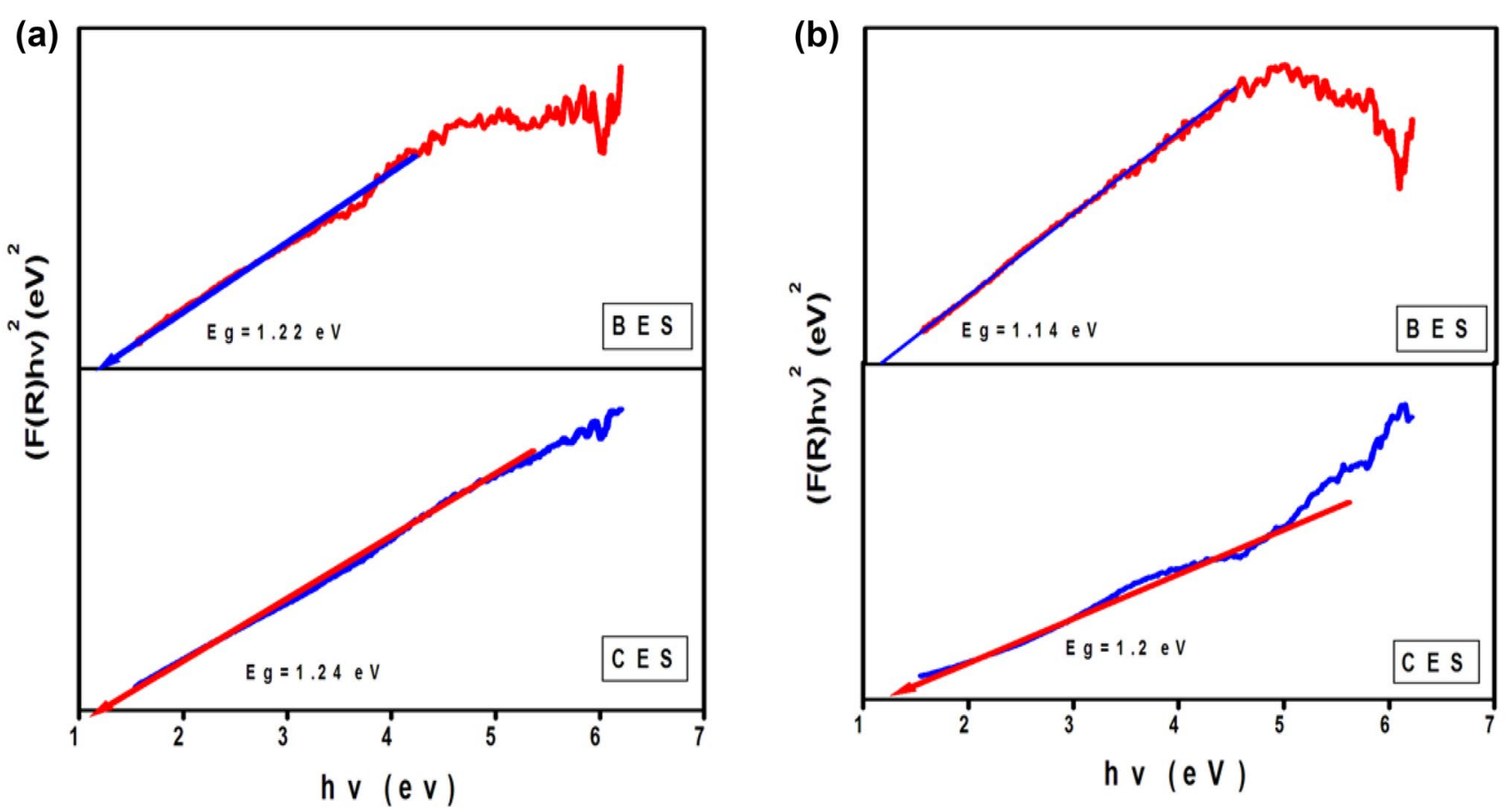

Fig. 8 Bandgap plot of Ac from BES and CES particles for $\mathbf{a}$ 4:1 and $\mathbf{b}$ 4:2 ratio
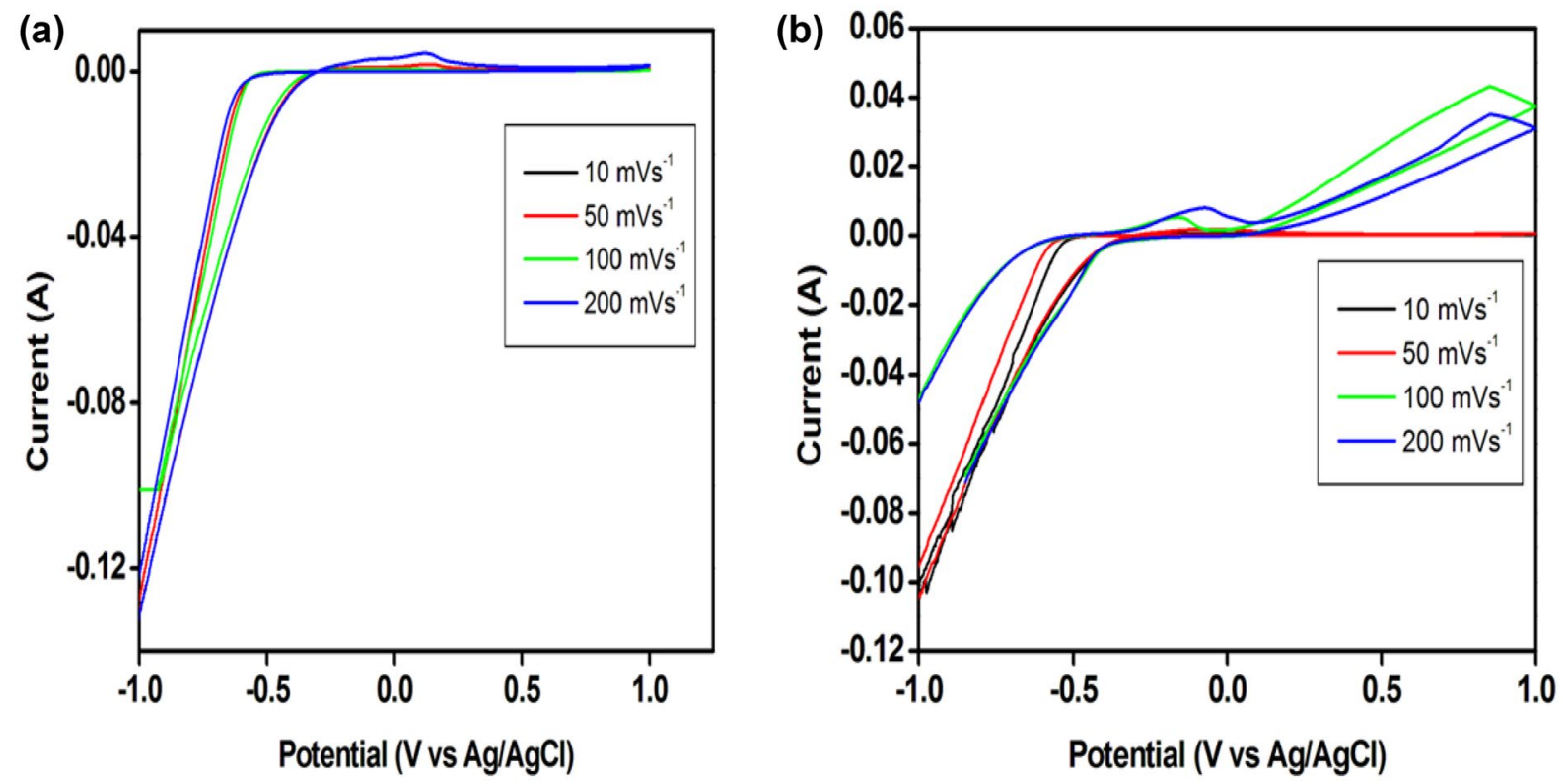

Fig. 9 CV plot of Ac from $\mathbf{a}$ BES and $\mathbf{b}$ CES for 4:1 concentration 

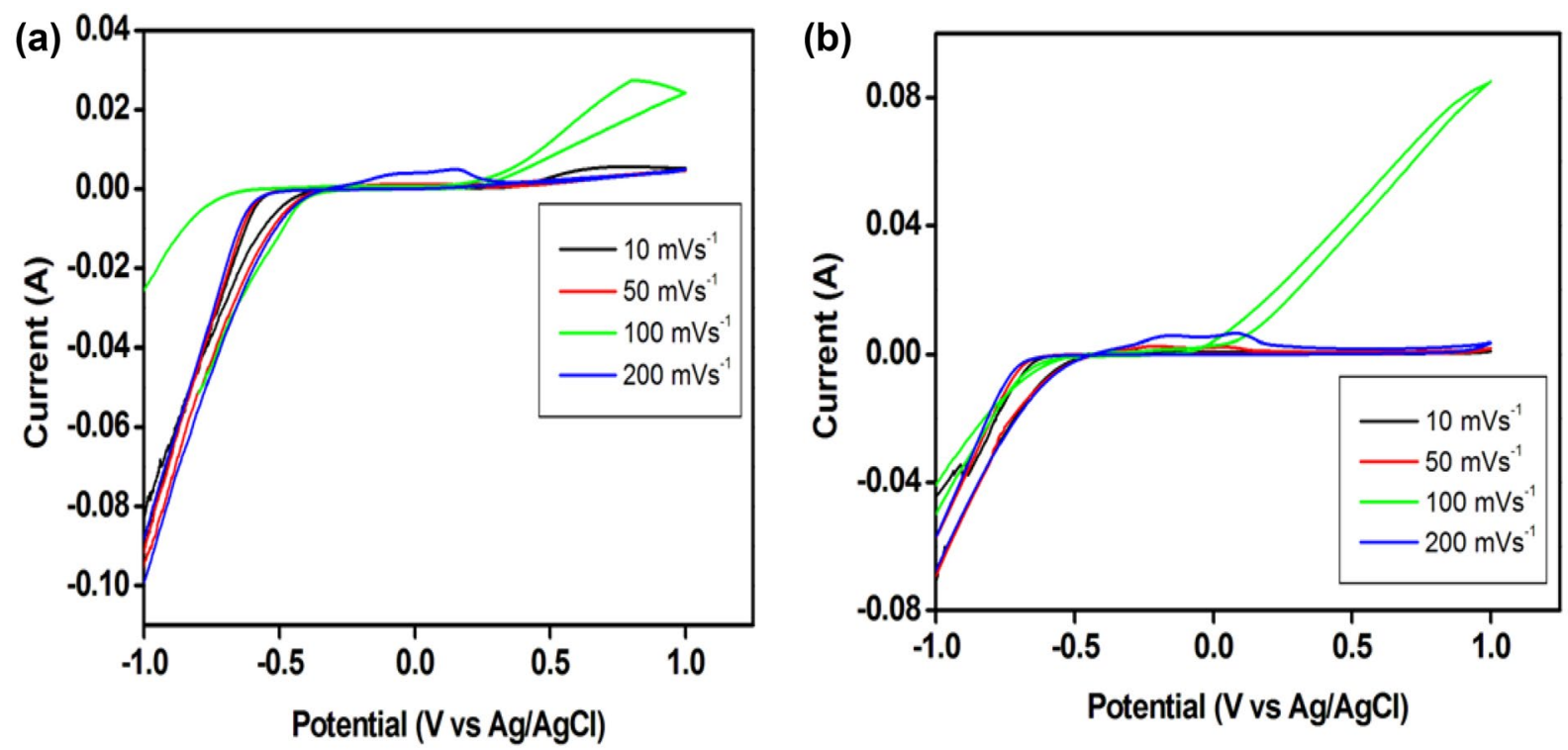

Fig. 10 CV plot of AC from BES and CES for 4:2 concentration

the material as witnessed by XRD and SEM analysis respectively.

\subsection{Cyclic voltammetry (cv)}

Figures 9 and 10 shows the CV curves of BES and CES for $4: 1$ and $4: 2$ concentration respectively. It is observed that the sample recorded at $10 \mathrm{mV} / \mathrm{s}$ exhibited higher integrated area since the particle seems to be highly dense. By using the CV curve the following parameter specific capacitance $\mathbf{C}_{\mathbf{s}}$ can be calculated from Eqs. 6 and 7 as

$\mathrm{C}_{\mathrm{a}}=\mathrm{l} /[\mathrm{dv} / \mathrm{dt}] \times \mathrm{S}\left(\mathrm{m} \mathrm{F} / \mathrm{cm}^{2}\right)$

$\mathrm{C}_{\mathrm{sp}}=\mathrm{C}_{\mathrm{a}} /$ mass of sample

where $C_{a}$ is the areal capacitance $(F), I$ is the integrated area of the CV curve, $d v / d t$ is the scan rate and $S$ is the surface area of the electroactive material. The variation of areal capacitance $\left(C_{a}\right)$ and specific capacitance $\left(C_{s p}\right)$ was calculated with respect to the different scan rates of the working electrode as tabulated in Table 4. When the scan rate increases, the $C_{s p}$ value gets decrease. The largest current in the BES sample revealed the excellent charge propagation in the electrodes. It is attributed to the electric double layer capacitor (EDLC) behavior. The narrow loop is due to larger resistance occurred in the samples due to the electrode/electrolyte interface. The irregular shape of the CV curve is due to water content, redox groups such as hydroxide group and carboxyl group [29, 30].

It is observed from Table 3 that the highest $C_{s p}$ value is found about $155.8 \mathrm{~F} / \mathrm{g}$ at $10 \mathrm{mV} / \mathrm{s}$ for BES which is due to higher areal capacitance. Similarly, CES has the highest $C_{s p}$ value of $144.83 \mathrm{~F} / \mathrm{g}$ at a scan rate of $10 \mathrm{mV} / \mathrm{s}$ that also indicates the enhanced capacitive performance. By comparing the results, the $\mathrm{AC}$ prepared from $\mathrm{BES}$ shows higher specific capacitance value.

By comparing the plots of $4: 2$ with $4: 1$ concentration, the loop of 4:2 is in a similar trend to that of 4:1 (BES and (CES), however, the magnitude of the integrated area is slightly varied (lower). It may be attributed to higher $\mathrm{CaCO}_{3}$ content formed during activation. As similar in the
Table 4 Different scan rates, areal capacitance $\left(\mathrm{C}_{\mathrm{a}}\right)$ and specific capacitance $\left(C_{\mathrm{sp}}\right)$

\begin{tabular}{|c|c|c|c|c|c|c|c|c|}
\hline \multirow{3}{*}{$\begin{array}{l}\text { Scan rate } \\
(\mathrm{mV} / \mathrm{s})\end{array}$} & \multicolumn{4}{|l|}{ BES } & \multicolumn{4}{|l|}{ CES } \\
\hline & \multicolumn{2}{|c|}{$\mathrm{C}_{\mathrm{a}}\left(\mathrm{mF} / \mathrm{cm}^{2}\right)$} & \multicolumn{2}{|c|}{$C_{s p}(F / g)$} & \multicolumn{2}{|c|}{$\mathrm{C}_{\mathrm{a}}\left(\mathrm{mF} / \mathrm{cm}^{2}\right)$} & \multicolumn{2}{|c|}{$C_{s p}(F / g)$} \\
\hline & $4: 1$ & $4: 2$ & $4: 1$ & $4: 2$ & $4: 1$ & $4: 2$ & $4: 1$ & $4: 2$ \\
\hline 10 & 9.31 & 8.20 & 155.80 & 133.95 & 8.69 & 4.62 & 144.83 & 66.37 \\
\hline 50 & 2.24 & 2.16 & 37.33 & 19.94 & 1.61 & 1.53 & 26.83 & 8.04 \\
\hline 100 & 7.69 & 5.92 & 128.22 & 90.91 & 0.10 & 0.09 & 1.73 & 1.42 \\
\hline 200 & 5.47 & 1.46 & 27.37 & 6.72 & 0.23 & 0.12 & 3.91 & 2.32 \\
\hline
\end{tabular}


case of 4:1 ratio, $C_{s}$ values found in 4:2 ratio are higher for both BES and CES for the scan rate of $10 \mathrm{mV} / \mathrm{s}$. From the analysis, 4:1 is found to be an optimum ratio for obtaining an efficient high performance energy storage device. Hence, the result suggests that a better activated carbon material identified from eggshell waste which is suitable for energy storage application.

\subsection{Electrochemical impedance spectra}

Figure 11 shows the EIS plot of BES and CES for 4:1 concentration. These measurements were employed to examine the performance of the working electrode (Ac) using a three-electrode cell in $0.5 \mathrm{M} \mathrm{H}_{2} \mathrm{SO}_{4}$ at the frequency range from 1 to $10 \mathrm{kHz}$ versus the $\mathrm{Ag} / \mathrm{AgCl}$ reference electrode. The EIS measurement shows semicircle nature for all the samples. From the equivalent circuit, $R, C$, and $L$ values are found and it is given in Table 5 .

The $x$-intercept at the beginning of the semicircle represents the equivalent series resistance including the electrolyte resistance, contact resistance at the interface between the electroactive material and substrate. The arc for the very high frequency corresponds to the charge transfer limiting process and was ascribed to the double layer capacitances in parallel with the charge transfer resistance at the contact interface between the
Table $5 \mathrm{R}, \mathrm{C}$ and $\mathrm{L}$ values for 4:1 concentration of BES and CES

electrode and electrolyte solution [31]. By comparing $B E S$ and CES, the sample BES shows the lowest value of $R_{S}$ and $R_{c t}$ value which indicates higher conductivity and better charge transport of electrolyte ion.

Figure 12 shows the EIS plot of BES and CES for $4: 2$ concentration. In the EIS of BES (Table 5) the charge transfer resistance $R_{(c t)}$ value get increased than $4: 1$ concentration, while it is lower than that of CES for 4:1 and $4: 2$. The $R, C$, and $L$ values for BES and CES for $4: 2$ concentration are given in Table 6.

The results clearly reveal that type of eggshell waste, as well as the content of the activation agent, plays a prominent role in identifying energy storage materials. By comparing the results of $R_{s}$ and $R_{c t}$ of BES ( $4: 1$ and 4:2) with CES, the BES shows lower values. Hence, it can be concluded from the analysis that BES found to be a potential material for energy storage devices.
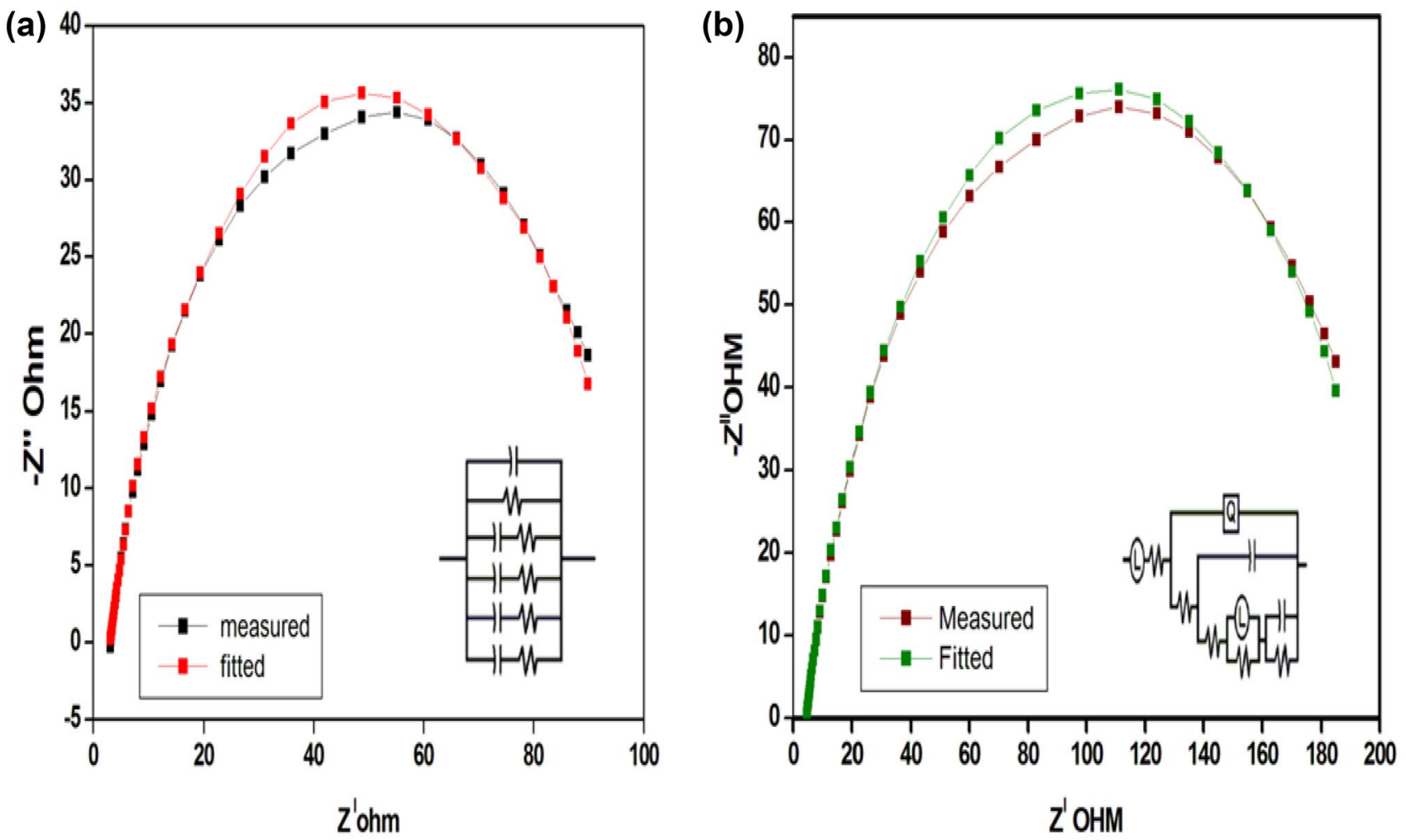

Fig. 11 Nyquist plot of ac from $\mathbf{a}$ BES and $\mathbf{b}$ CES at 4:1 and its equivalent circuit 

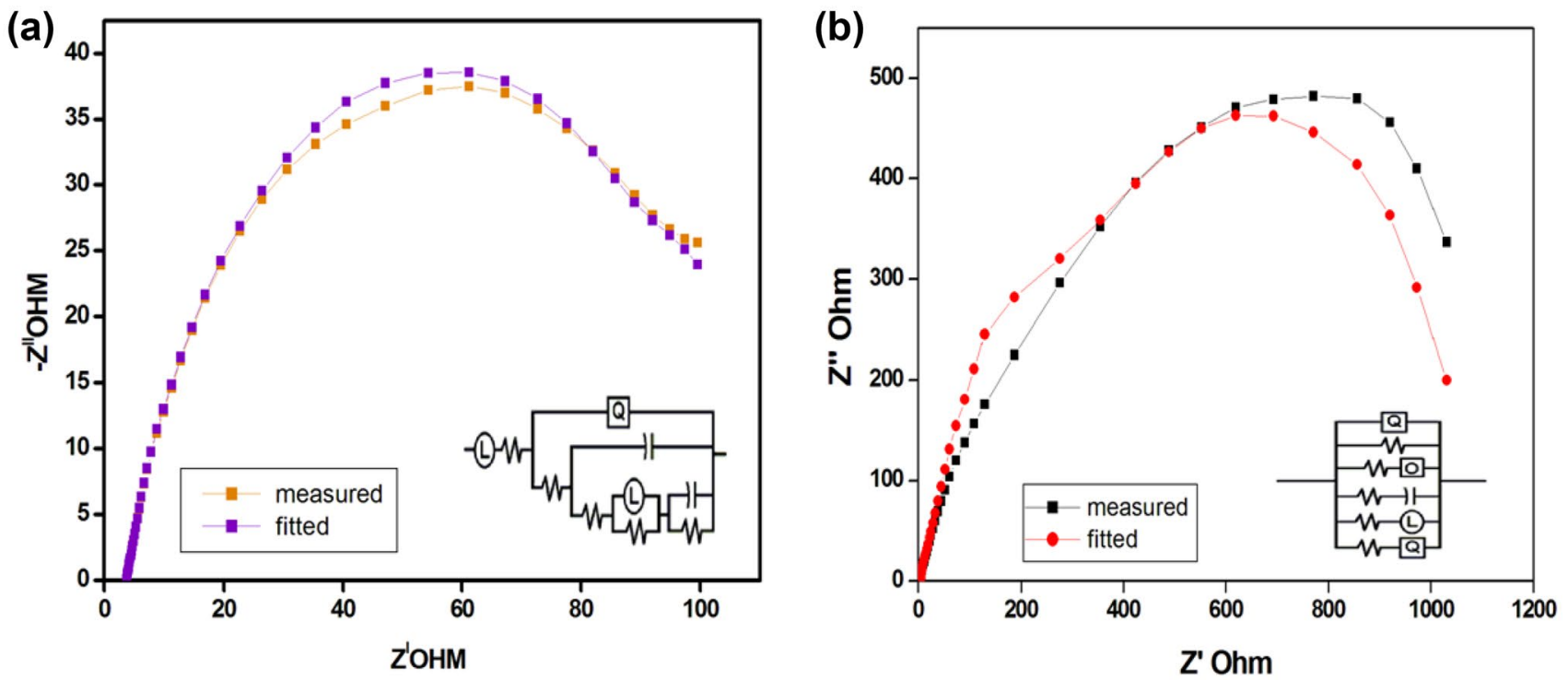

Fig. 12 Nyquist plot of ac from $\mathbf{a}$ BES and $\mathbf{b}$ CES at 4:2 and its equivalent circuit

Table $6 \mathrm{R}, \mathrm{C}$ and $\mathrm{L}$ values for 4:2 concentration of BES and CES

\begin{tabular}{lll}
\hline & BES & CES \\
\hline $\mathrm{R}_{\mathrm{S}}(\Omega)$ & 9.58 & 10.26 \\
$\mathrm{R}_{\mathrm{Ct}}(\Omega)$ & 53.39 & 127.42 \\
$\mathrm{~L}$ & $4.985 \mathrm{E}-8$ & $4.995 \mathrm{E}-8$ \\
$\mathrm{C}$ & $7.123 \mathrm{E}-5$ & $6.174 \mathrm{E}-5$
\end{tabular}

\section{Conclusion}

In the study, activated carbon was prepared using broiler hen eggshell and Country hen eggshell for $4: 1$ and $4: 2$ concentrations of $\mathrm{H}_{3} \mathrm{PO}_{4}$. The XRD pattern confirmed the hexagonal structure of $A C$ observed with peak shift, single and multi-crystalline structure. From the FTIR spectra, the presence of vibrational bands of CES is identical to $B E S$, with slight variation observed in the intensity of the peaks. From UV-Vis DRS analysis, BES exhibited strong absorption in the visible region in comparison to CES. The bandgap values of BES and CES are almost identical to each other. Interestingly, the surface morphology reveals the irregular shape and size of particles observed for BES which are dense and porous nature while CES shows less dense with particular geometrical shape of the particles. It could be attributed to the influence of activating agent $\mathrm{H}_{3} \mathrm{PO}_{4}$ on the different types of eggshells. From the $\mathrm{CV}$ analysis, the sample BES has achieved a higher specific capacitance value of $156 \mathrm{~F} / \mathrm{g}$ compared to CES as supported by the EIS measurements that BES has the lowest $R_{s}$ and $R_{c t}$ values and hence exhibited better conductivity and charge storage. From the proximate analysis ash content, moisture content, specific gravity, bulk density, and porosity can be calculated.

Acknowledgements The authors acknowledge DST-SERB, New Delhi for providing financial support under Extra Mural Research (F. No. EMR/2017/000351) fund. The author is grateful to Kalasalingam University for SEM analysis. The authors are thankful to the DST-FIST and UGC-SAP (DRS-I and II) for providing financial support to the Department of Physics, Manonmaniam Sundaranar University.

\section{Compliance with ethical standards}

Conflict of interest The authors declare that they have no conflict of interest.

\section{References}

1. Rufford TE, Hulicova-Jurcakova D, Zhu Z, Gao Qing L (2008) Nanoporous carbon electrode from waste coffee beans for high performance supercapacitors. Electrochem Commun 10:1594-1597

2. Zequine C, Ranaweera CK, Wang Z, Singh S, Tripathi P, Srivastava ON, Gupta BK, Ramasamy K, Kahol PK, Dvornic PR, Gupta RK (2016) High performance and flexible supercapacitors based on carbonized bamboo fibers for wide temperature applications. Sci Rep 6:31704

3. González-García P, Centeno TA, Urones-Garrote E, Ávila-Brande D, Otero-Díaz LC (2013) Microstructure and surface properties of lignocellulosic-based activated carbons. Appl Surf Sci 265:731-737

4. Kalderis D, Bethanis S, Paraskeva P, Diamadopoulos E (2008) Production of activated carbon from bagasse and rice husk by a single-stage chemical activation method at low retention times. Biores Technol 99:6809-6816

5. Rufford TE, Hulicova-Jurcakova D, Khosla K, Zhu Z, Gao Qing $L$ (2010) Microstructure and electrochemical double-layer 
capacitance of carbon electrodes prepared by zinc chloride activation of sugar cane bagasse. J Power Sources 195:912-918

6. Foo KY, Hameed BH (2011) Utilization of rice husks as a feedstock for preparation of activated carbon by microwave-induced $\mathrm{KOH}$ and $\mathrm{K}_{2} \mathrm{CO}_{3}$ activation. Biores Technol 102:9814-9817

7. He X, Ling P, Qiu J, Moxin Yu, Zhang X, Chang Yu, Zheng M (2013) Efficient preparation of biomass-based mesoporous carbons for supercapacitors with both high energy density and high power density. J Power Sources 240:109-113

8. Taer E, Deraman M, Talib IA, Awitdrus A, Hashmi SA, Umar AA (2011) Preparation of a highly porous binderless activated carbon monolith from rubberwood sawdust by a multi-step activation process for application in supercapacitors. Int J Electrochem Sci 6:3301-3315

9. Zhang S, Shi X, Chen X, Zhang D, Liu X, Zhang Z, Mijowska E (2019) Large-scale and low-cost motivation of nitrogen-doped commercial activated carbon for high-energy-density supercapacitor. ACS Appl Energy Mater 6:4234-4243

10. Bhomick PC, Supong A, Karmaker R, Baruah M, Pongener C, Sinha D (2019) Activated carbon synthesized from biomass material using single-step $\mathrm{KOH}$ activation for adsorption of fluoride: experimental and theoretical investigation. Korean J Chem Eng 4:551-562

11. Sivachidambaram $M$, Judith Vijaya J, John Kennedy $L$, Jothiramalingam R, Al-Lohedan HA, Munusamy MA, Elanthamilane E, Princy Merline J (2017) Preparation and characterization of activated carbon derived from the Borassus flabellifer flower as an electrode material for supercapacitor applications. RCS New J Chem 41:3939-3949

12. Li Z, Zhang L, Amirkhiz BS, Tan $X$, Zhanwei $X$, Wang $H$, Olsen BC, Holt Chris MB, Mitlin D (2012) Carbonized chicken eggshell membrane with 3D architectures as high performance electrode. Adv Energy Mater 2:431-437

13. Meng X, Deng D (2016) Trash to treasure: waste eggshells used as reactor and template for synthesis of $\mathrm{Co}_{9} \mathrm{~S}_{8}$ nanorod arrays on carbon fibers for energy storage. Chem Mater 28:3897-3904

14. Alcaraz-Espinoza JJ, Pinto C, de Melo H, de Oliveira P (2017) Fabrication of highly flexible hierarchical polypyrrole/carbon nanotube on eggshell membranes for supercapacitors. ACS Omega 2:2866-2877

15. Yang P, Xie J, Zhong C (2018) Biowaste-derived three-dimensional porous network carbon and bioseparator for high-performance asymmetric supercapacitor. ACS Appl Energy Mater 1:616-622

16. Ekpete OA, Horsfall MJNR (2011) Preparation and characterization of activated carbon derived from fluted pumpkin stem waste. (Telfairia occidentalis Hook F). Res J Chem Sci 3:10-17

17. Cree D, Rutter A (2015) Sustainable bio-inspired limestone eggshell powder for potential industrialized applications. ACS Sustain Chem Eng 3:941-949

18. Mopoung S, Jitchaijaroenkul K (2017) Characterization of activated carbon from eggshell membranes prepared using sodium acetate and zinc metal activation. Am J Appl Sci 14:737-747
19. Durai G, Kuppusami P, Viswanathan K (2018) Investigation on microstructure and improved supercapacitive performance of $\mathrm{Mn}$-doped $\mathrm{CuO}$ thin films prepared by reactive radio frequency magnetron sputtering. J Mater Sci Mater Electron 29(3):2051-2058

20. Carvalho J, Araujo J, Castro F (2011) Alternative low-cost adsorbent for water and wastewater decontamination derived from eggshell waste: an overview. Waste Biomass Valorization 2:157-167

21. Tangboriboon N, Kunanuruksapong R, Sirivat A (2012) Preparation and properties of calcium oxide from eggshells via calcination. Mater Sci Pol 30:313-322

22. Corrêa THA, Holanda JNF (2016) Calcium pyrophosphate powder derived from avian eggshell waste. Cerâmica 62:278-280

23. Salma K, Borodajenko N, Plata A, Berzina-Cimdina L, Stunda A (2008) Fourier transform infrared spectra of technologically modified calcium phosphates. In: 14th Nordic-Baltic conference on biomedical engineering and medical physics, pp 68-71. Springer, Berlin

24. Borhade AV, Kale AS (2017) Calcined eggshell as a cost-effective material for the removal of dyes from aqueous solution. Appl Water Sci 7:4255-4268

25. Al-Ghouti MA, Salih NR (2018) Application of eggshell wastes for boron remediation from water. J Mol Liq 256:599-610

26. Ahmed S, Ahmed A, Rafat M (2018) Supercapacitor performance of activated carbon derived from rotten carrot in aqueous, organic and ionic liquid-based electrolytes. J Saudi Chem Soc 8:993-1002

27. Sixiao H, Hsieh Y-L (2014) Preparation of activated carbon and silica particles from rice straw. ACS Sustain Chem Eng 2:726-734

28. Ummartyotin S, Tangnorawich B (2015) Utilization of eggshell waste as raw material for the synthesis of hydroxyapatite. Colloid Polym Sci 293:2477-2483

29. Natalia M, Sudhakar YN, Selvakumar M (2013) Activated carbon derived from natural sources and electrochemical capacitance of double layer capacitor. Indian J Chem Technol 20:392-399

30. Li Z, Zhanwei X, Tan X, Wang H, Holt CM, Stephenson T, Olsen BC, Mitlin D (2013) Mesoporous nitrogen-rich carbons derived from protein for ultra-high capacity battery anodes and supercapacitors. Energy Environ Sci 6:871-878

31. Liu X, Yin C, Yang J, Liang M, Wei J, Zhang Z, Wang H, Wang $Q$ (2016) Controllable preparation of an eggshell membrane supported hydrogel electrolyte with thickness-dependent electrochemical performance. J Mater Chem A 46:17933-17938

Publisher's Note Springer Nature remains neutral with regard to jurisdictional claims in published maps and institutional affiliations. 